\title{
Fungal disease of freshwater fishes in Natore district of Bangladesh
}

\author{
M. A. B. Siddique, M. A. Bashar ${ }^{1}$, M. A. Hussain and A. S. M. Kibria ${ }^{2}$ \\ Department of Fisheries, Rajshahi University, Rajshahi-6205, Bangladesh \\ ${ }_{1}^{1}$ Department of Aquaculture, Bangladesh Agricultural University, Mymensingh-2202, Bangladesh \\ ${ }^{2}$ Department of Aquaculture Hajee Mohammad Danesh Science and Technology University. Dinajpur, Bangladesh
}

\begin{abstract}
An investigation was conducted on fungal disease of freshwater fishes in Natore district of Bangladesh from September 2005 to February 2006. A total of 2097 fish specimens where about 300 fishes under 15 fish species (8 culturable and 7 non culturable) were infected with fungal disease. Among culturable species most fungal infected fishes was C. mrigala (24.71\%) where the total length, total weight and group of this infected fish was 10.8 to $40 \mathrm{~cm}, 10$ to $995 \mathrm{~g}$ and 10.1 to $15 \mathrm{~cm}$ respectively followed by C. idellus (16.28\%) and L. rohita (13.43\%). Among non culturable species the most fungal infected fish was C. punctatus (22.42\%) where the total length, total weight and group of this infected fish was 11 to $23 \mathrm{~cm}, 15$ to $20 \mathrm{~g}$ and 20.1 to $25 \mathrm{~cm}$ respectively followed by C. striatus (16.88\%) and $P$. ticto (15.31\%). Disease in culturable fish species was less (13.40\%) than nonculturable species (15.19\%). Three genera of fungi were identified where Branchiomyces sp. was associated with gill rot disease and Saprolegnia sp. and Aphanomyces sp. were associated with ulcer types of disease. The incidence (\%) of disease was highest in the month of December (22.49\%) followed by November (20.25\%) and January (18.00\%).
\end{abstract}

Keywords: Fungal disease, Infected fish, Incidence

\section{Introduction}

Diseases in freshwater fishes in Bangladesh are a great threat to achieve optimum production and become a limiting factor to economic success of aquaculture. The open water capture fish has been suffering from various types of diseases such as epizootic ulcerative syndrome (EUS), septicemia, tail and fin rot disease, gill rot disease, viral disease, bacterial disease and fungal disease (Chowdhury, 1993, 1997). Fungi, which cause fungal disease, are present in salt or freshwater. In most cases, fungi serve a valuable ecological function by processing dead organic debris. However fungi can become a problem if fish are stressed by poor nutrition, pressure of population and over exploitation of fishes. Fungal infections of freshwater fish are common and distributed world wide and associated with immune suppression. Fungal diseases are easily recognized by relatively superficial, colony of fluffy growth on the skin and gill of fishes. Myazaki and Egusa (1973) observed an invasive component in histological section of ulcerative disease affected as mycotic granulomatosis (MG). Similarity McKenzic and Hall (1976) identified mycotic granulomass in histological sections of the early outbreak of EUS in Southeast Asia. Achyla, Saprolegnia and Aphanomyces were commonly identified from the lesion surface of affected fish (Roberts et al. 1993). Research on fungal disease in relatively new but a few number of research work has been conducted on specific region. Therefore the present study has been aimed to isolate, identify and determine the pathogenocity of the fish.

\section{Materials and Methods}

Study area: For the investigation, different water bodies (Ponds and other water bodies) and landing center of sadar upazila, Natore district of Bangladesh was selected as a study area.

Collection of diseased fishes: The diseased fishes were collected randomly every week at regular interval from the study area. Data were collected from fish farmers, fishermen and fish traders about fish disease. Secondary information on fish disease was also collected from DFO and UFO of the study area.

Sampling techniques: The infected fishes were identified by the symptoms of fishes such as loss of normal glaze; spot having hemorrhagic lesions on the body, excess mucus secretions, discoloration of gill filament and damage of gill. For the isolation of fungus fishes were carried to the laboratory immediately after collection. 
Isolation of fungus: PDA (Potato Dextrose Agar) media was used as a culture media for the isolation and to find out the fungus. At first infected fishes were cut in cross section, using a flamed scalpel. A small block of muscle was removed from the lesion. Blocks of tissue were removed and placed into petridishes, washed with $15 \mathrm{ml}$ distilled water. Then the tissue blocks were transferred into the culture media petridishes. Then petridishes were inverted with parafilm and kept in incubator at $25{ }^{\circ} \mathrm{C}$ for 3 days, until a circular fungal mat developed. These were used during subculture of the fungus.

A suitable portion of culture plates of different colony from PDA was taken out with the help of forceps or needle and put on a slice in 1 or 2 drops at cotton blue on clear slide. Then it was warmed by spirit lamp 6-8 times and it was then examined under a compound microscope. Incidence of fungal disease of infected fishes was calculated by following formula:

Incidence $(\%)=($ No. of fish infected $/$ No. of fish Examined $) \times 100$

Physico-chemical condition of ponds: The Physico-chemical parameters (water temperature, transparency, $\mathrm{DO}, \mathrm{CO}_{2}, \mathrm{pH}$ and total hardness) were measured weekly of the sampling ponds during the study period. All the collected data were analyzed with the help of MS-Excel and calculator.

\section{Results and Discussion}

It was observed that a total of 2097 fish specimens of which 300 species (8 culturable 7 non culturable) were infected with fungal disease. It was observed that the fugal disease of culturable fish was less (13.40\%) than the non-culture fish species (15.19\%). C. mrigala was most susceptible to fungal disease showing incidence as $(24.71 \%)$ followed by $C$. idella $(16.28 \%)$ whereas $H$. molitrix was least susceptible (2.83\%). The infected fish species and their incidence (\%) are shown in Table 1.

During the study period three genera of fungus such as Saprolegnia, Aphanomyces and Branchiomyces were identified from dermal lesion, gill of the studied infected fish specimens where Saprolegnia and Aphanomyces were associated with ulcer type disease of lesion and Branchiomyces was associated with gill rot disease. All types of pathogenic fungus were identified from $L$. rohita, $C$. catla, C. mrigala. Saprolegnia and Aphanomyces were identified from C. punctatus, C. striatus, C. batrachus, $H$. fosillis and $A$. testudineus. Saprolegnia and Branchiomyces were isolated from Cyprinus carpio var. communis and Cyprinus carpio var. specularis. Aphanomyces and Branchiomyces were isolated from C. idella and only Saprolegnia was isolated from $P$. gonionotus, $P$. ticto $H$. molitrix and M. vittaus (Table 2).

Table 1. Fungal disease infected fish species and their incidence of the study area during the study period

\begin{tabular}{|c|c|c|c|c|}
\hline \multirow{2}{*}{$\begin{array}{l}\text { SL. } \\
\text { No. }\end{array}$} & \multirow{2}{*}{ Species } & \multicolumn{2}{|c|}{ No. of fish } & \multirow{2}{*}{ Incidence (\%) } \\
\hline & & Observed & Infected & \\
\hline \multicolumn{5}{|c|}{ Culturable species } \\
\hline 01 & C. catla & 88 & 8 & 9.09 \\
\hline 02 & L. rohita & 67 & 9 & 13.43 \\
\hline 03 & C. mrigala & 178 & 44 & 24.72 \\
\hline 04 & H. molitrix & 106 & 3 & 2.83 \\
\hline 05 & C. idellus & 129 & 21 & 16.28 \\
\hline 06 & C. carpio var. specularis & 188 & 24 & 12.77 \\
\hline 07 & C. carpio var. cummunis & 107 & 13 & 12.15 \\
\hline 08 & P. gonionotus & 174 & 17 & 9.77 \\
\hline \multicolumn{2}{|l|}{ Sub total } & 1037 & 139 & 13.40 \\
\hline \multicolumn{5}{|c|}{ Non-culturable species } \\
\hline 09 & P. ticto & 209 & 32 & 15.31 \\
\hline 10 & C. punctatus & 281 & 63 & 22.42 \\
\hline 11 & C. striatus & 154 & 26 & 16.88 \\
\hline 12 & C. batrachus & 133 & 13 & 9.77 \\
\hline 13 & H. fosillis & 92 & 12 & 13.04 \\
\hline 14 & M. vittatus & 89 & 2 & 2.24 \\
\hline 15 & A. testudineus & 102 & 13 & 12.75 \\
\hline \multicolumn{2}{|l|}{ Sub total } & 1060 & 161 & 15.19 \\
\hline \multicolumn{2}{|l|}{ Total } & 2097 & 300 & 14.31 \\
\hline
\end{tabular}


Table 2. Range of total length, total weight, site of isolation, infected fungi and symptoms of infected fish species during the study period

\begin{tabular}{|l|c|c|c|c|c|}
\hline Species & $\begin{array}{c}\text { Range of total } \\
\text { length }(\mathrm{cm})\end{array}$ & $\begin{array}{c}\text { Range of total } \\
\text { weight }(\mathrm{g})\end{array}$ & $\begin{array}{c}\text { Site of } \\
\text { isolation }\end{array}$ & $\begin{array}{c}\text { Infected } \\
\text { fungi }\end{array}$ & Symptoms \\
\hline C. catla & $8.0-25$ & $05-380$ & Lesion, gill & $\mathrm{S}, \mathrm{A}, \mathrm{B}$ & Ulcer, gill rot \\
\hline L. rohita & $8.30-30$ & $05-290$ & Lesion, gill & $\mathrm{S}, \mathrm{A}, \mathrm{B}$ & Ulcer, gill rot \\
\hline C. mrigala & $10.8-40$ & $10-995$ & Lesion, gill & $\mathrm{S}, \mathrm{A}, \mathrm{B}$ & Ulcer, gill rot \\
\hline H. molitrix & $10-15$ & $10-12$ & Lesion, gill & $\mathrm{S}$ & Ulcer \\
\hline C. idellus & $8-50$ & $7-1800$ & Lesion, gill & $\mathrm{A}, \mathrm{B}$ & Ulcer, gill rot \\
\hline C. carpio var. specularis & $15-55$ & $12-2000$ & Lesion, gill & $\mathrm{S}, \mathrm{B}$ & Ulcer, gill rot \\
\hline C. carpio var. cummunis & $15-55$ & $12-2000$ & Lesion, gill & $\mathrm{S}, \mathrm{B}$ & Ulcer, gill rot \\
\hline P. gonionotus & $12.5-19$ & $25-100$ & Lesion, gill & $\mathrm{S}, \mathrm{A}$ & Ulcer \\
\hline P. ticto & $6.1-11$ & $5-17$ & Lesion & $\mathrm{S}, \mathrm{A}$ & Ulcer \\
\hline C. punctatus & $11-23$ & $15-20$ & Lesion & $\mathrm{S}, \mathrm{A}, \mathrm{B}$ & Ulcer \\
\hline C. striatus & $11-33$ & $15-25$ & Lesion & $\mathrm{S}, \mathrm{A}$ & Ulcer \\
\hline C. batrachus & $22-32$ & $17-23$ & Lesion & $\mathrm{S}, \mathrm{A}$ & Ulcer \\
\hline H. fosillis & $8-22$ & $5-18$ & Lesion & $\mathrm{S}, \mathrm{A}$ & Ulcer \\
\hline M. vittatus & $5-12$ & $4-7$ & Lesion & $\mathrm{S}$ & Ulcer \\
\hline A. testudineus & $8.1-13.1$ & $5-8$ & Lesion & $\mathrm{S}, \mathrm{A}$ & Ulcer \\
\hline
\end{tabular}

Note: $\mathrm{S}=$ Saprolegnia, $\mathrm{A}=$ Aphanomyces and $\mathrm{B}=$ Branchiomyces

\section{Description of fungal disease infected fish species}

Range of total length and total weight, site of isolation and isolated fungus and symptoms of fungal disease infected fishes are shown in Table 2 and size frequency distribution of infected fish species are shown in Table 3.

Table 3. Size frequency distribution of fungal disease infected fish species

\begin{tabular}{|c|c|c|c|c|c|c|c|c|c|c|}
\hline \multirow{2}{*}{ Species } & \multicolumn{10}{|c|}{ Length of group (cm) } \\
\hline & $5-10$ & $10.1-15$ & $15.1-20$ & $20.1-25$ & 25.1-30 & 30.1-35 & $35.1-40$ & 40.1-45 & $45.1-50$ & $50.1-55$ \\
\hline \multicolumn{11}{|c|}{ Culturable species } \\
\hline C. catla & 1 & 2 & 1 & 4 & - & - & - & - & - & - \\
\hline L. rohita & 1 & 3 & 1 & 2 & 2 & - & - & - & - & - \\
\hline C. mrigala & 2 & 14 & 5 & 4 & 7 & 8 & 4 & - & - & - \\
\hline H. molitrix & - & 3 & - & - & - & - & - & - & - & - \\
\hline C. idellus & 1 & 7 & 2 & 1 & - & & 2 & - & 3 & - \\
\hline $\begin{array}{l}\text { C. carpio } \\
\text { var.specularis }\end{array}$ & - & 5 & 3 & 2 & 2 & 6 & - & 4 & - & 2 \\
\hline $\begin{array}{l}\text { C. carpio } \\
\text { var.cummunis }\end{array}$ & - & - & - & 1 & 3 & 7 & - & - & - & 2 \\
\hline P. gonionotus & - & 7 & 10 & - & - & - & - & - & - & - \\
\hline Sub total & 5 & 41 & 22 & 14 & 14 & 26 & 6 & 4 & 3 & 4 \\
\hline \multicolumn{11}{|c|}{ Non culturable species } \\
\hline P. ticto & 19 & 13 & - & - & - & - & - & - & - & - \\
\hline C. punctatus & - & 20 & 15 & 28 & - & - & - & - & - & - \\
\hline C. striatus & - & - & 2 & 8 & 13 & 1 & 2 & - & - & - \\
\hline C. batrachus & - & - & - & 5 & 2 & 6 & - & - & - & - \\
\hline H. fosillis & 3 & 2 & 4 & 3 & - & - & - & - & - & - \\
\hline M. vittatus & - & 2 & - & - & - & - & - & - & - & - \\
\hline A. testudineus & 6 & 7 & - & - & - & - & - & - & - & - \\
\hline Sub total & 28 & 44 & 21 & 44 & 15 & 7 & 2 & - & - & - \\
\hline Total & 33 & 85 & 43 & 58 & 29 & 33 & 8 & 4 & 3 & 4 \\
\hline
\end{tabular}

Note: (-) means none

\section{Culturable Species}

Catla catla: A total of 8 fungal infected fish specimens were examined during the study period where symptoms were recorded as ulcer, gill rot and scale loss. The total length and total weight of infected fish ranged from 8.1 to $25 \mathrm{~cm}$ and 5 to $380 \mathrm{~g}$ respectively where most infected group (4) was 20.1 to $25 \mathrm{~cm}$. 
Labeo rohita: A total of 9 fungal infected fish specimens were examined from September to November and January to February where symptoms were recorded as ulcer, EUS and gill rot. The total length and total weight of infected fish ranged from 8.3 to $30 \mathrm{~cm}$ and 5 to $29 \mathrm{~g}$ respectively where most infected group (3) was 10.1 to $15 \mathrm{~cm}$.

Cirrhinus mrigala: A total of 44 fungal infected fish specimens were examined from October to December and January to February where symptoms were recorded as ulcer, EUS and gill rot. The total length and total weight of infected fish ranged from 10.8 to $40 \mathrm{~cm}$ and 10 to $995 \mathrm{~g}$ respectively where most infected group (14) was 10.1 to $15 \mathrm{~cm}$.

Ctenopharyngodon idella: A total of 21 fungal infected fish specimens were examined from November to February where symptoms were recorded as dermal lesion, ulcer, EUS and gill rot. The total length and total weight of infected fish ranged from 8 to $50 \mathrm{~cm}$ and 7 to $1800 \mathrm{~g}$ respectively where most infected group (7) was 10.1 to $15 \mathrm{~cm}$.

Hypophthalmichthys molitrix: A total of 3 fungal infected fish specimens were examined during the study period where symptoms were recorded as ulcer and EUS. The total length and total weight of infected fish ranged from 10 to $15 \mathrm{~cm}$ and 10 to $12 \mathrm{~g}$ respectively where most infected group (3) was 10.1 to $15 \mathrm{~cm}$.

Cyprinus carpio var. specularis: A total of 24 fungal infected fish specimens were examined from September to January where symptoms were recorded as dermal lesion over all the body, ulcer, EUS and gill rot. The total length and total weight of infected fish ranged from 15 to $55 \mathrm{~cm}$ and 12 to $2000 \mathrm{~g}$ respectively where most infected group (6) was 31.1 to $35 \mathrm{~cm}$.

Cyprinus carpio var communis: A total of 24 infected fish specimens with fungus were examined during the investigation where symptoms were recorded as ulcer and gill rot. The total length and total weight of infected fish ranged from 15 to $55 \mathrm{~cm}$ and 12 to $2000 \mathrm{~g}$ respectively where most infected group (7) was 31.1 to $35 \mathrm{~cm}$.

Puntius gonionotus: A total of 17 infected fish specimens with fungus were examined from December to January where symptoms were recorded as ulcer. The total length and total weight of infected fish ranged from 12.5 to $19 \mathrm{~cm}$ and 25 to $100 \mathrm{~g}$ respectively where most infected group (10) was 15.1 to $20 \mathrm{~cm}$.

\section{Non-Culturable Species}

Puntius ticto: A total of 32 infected fish specimens with fungus were examined from October to January where symptoms were recorded as ulcer. The total length and total weight of infected fish ranged from 6.1 to $11 \mathrm{~cm}$ and 5 to $17 \mathrm{~g}$ respectively where most infected group (19) was 5.1 to $10 \mathrm{~cm}$.

Channa punctatus: A total of 63 infected fish specimens with fungus were examined from November to January where symptoms were recorded as ulcer. The total length and total weight of infected fish ranged from 11 to $23 \mathrm{~cm}$ and 15 to $20 \mathrm{~g}$ respectively where most infected group (28) was 20.1 to 25 $\mathrm{cm}$.

Channa striatus: A total of 26 infected fish specimens with fungus were examined from November to January where symptoms were recorded as ulcer. The total length and total weight of infected fish ranged from 11 to $33 \mathrm{~cm}$ and 15 to $25 \mathrm{~g}$ respectively where most infected group (23) was 25.1 to 30 $\mathrm{cm}$.

Clarias batrachus: A total of 23 infected fish specimens with fungus were examined from January to February where symptoms were recorded as ulcer. The total length and total weight of infected fish ranged from 22 to $32 \mathrm{~cm}$ and 17 to $23 \mathrm{~g}$ respectively where most infected group (6) was 30.1 to 35 $\mathrm{cm}$.

Heteropneustes fosillis: A total of 12 infected fish specimens with fungus were examined from November to February where symptoms were recorded as ulcer. The total length and total weight of infected fish ranged from 8 to $22 \mathrm{~cm}$ and 5 to $18 \mathrm{~g}$ respectively where most infected group (4) was 15.1 to $20 \mathrm{~cm}$. 
Mystus vittatus: A total of 2 infected fish specimens with fungus were examined from December to February where symptoms were recorded as ulcer. The total length and total weight of infected fish ranged from 6 to $12 \mathrm{~cm}$ and 4 to $7 \mathrm{~g}$ respectively where most infected group (2) was 10.1 to $15 \mathrm{~cm}$.

Anabas testudineus: A total of 13 infected fish specimens with fungus were examined from November to February where symptoms were recorded as ulcer. The total length and total weight of infected fish ranged from 8.1 to $13.1 \mathrm{~cm}$ and 5 to $8 \mathrm{~g}$ respectively where most infected group (7) was 10.1 to $15 \mathrm{~cm}$.

During the investigation it was observed that month wise highest incidence was $22.49 \%$ in the month of December followed by November (20.25\%) and January (18\%) (Table 4). It was also observed that the water quality parameters such as water temperature, water transparency, $\mathrm{pH}, \mathrm{DO}$, free $\mathrm{CO}_{2}$, and total hardness showed lowest value from in the month of December to February.

Table 4. Monthly variation of incidence of fungal disease fish during the study period

\begin{tabular}{|l|c|c|c|}
\hline \multirow{2}{*}{ Month } & \multicolumn{2}{|c|}{ Number of fish } & \multirow{2}{*}{ Incidence (\%) } \\
\cline { 2 - 3 } & Observed & Infected & 8.13 \\
\hline September & 369 & 30 & 8.33 \\
\hline October & 348 & 29 & 20.25 \\
\hline November & 385 & 78 & 22.49 \\
\hline December & 378 & 85 & 18.00 \\
\hline January & 297 & 55 & 7.19 \\
\hline February & 320 & 23 & 14.31 \\
\hline Total & 2097 & 300 & . \\
\hline
\end{tabular}

It was observed that the freshwater fishes of Natore sadar upazila suffer from three types of fungal diseases including Saprolegniasis, Aphanomyces and Branchiomyces were found during the study period. Among them C. mrigala, $C$. punctatus and $C$. striatus were most infected species. It is almost similar with Alam et al. (2003) who found that C. mrigala and C. striatus were most severely infected fishes in Bogra and Naogaon district. Saprolegnia sp. and Aphanomyces sp. were recovered from ulcer type lesion affected fishes and Branchiomyces sp. recovered from affected gill. Infections of fish were frequently associated with wounds or lesion and handling damage of fish skin may predispose them to infection. Chinabut (1994) isolated this species of fungi from EUS affected fish where Aphanomyces sp. was isolated from natural lesions. Willoughby et al. (1994) reported that Aphanomyces sp. pathogen was isolated from $X$. cancila, L. rohita, C. punctatus and C. striatus of Bangladesh. Sineszko (1974) and Roberts et al. (1993) also reported that the genera of Aphanomyces sp. were recovered from the surface lesion of EUS infected fish both from Thailand and Bangladesh. The types of ulcers produced in fish from India and Pakistan have been associated with pathogenic fungus Saprolegnia sp. (Anonymous, 1992 and Rab et al. 2001). Jewel and Affan (2003) found that Aphanomyces sp. and Saprolegnia sp. were common pathogens in L. rohita, C. catla, $P$. gonionotus and C. punctatus of Bogra district. Bruno and Wood (1994) stated that Saprolegnia sp. has great impact on aquaculture especially it can infect carp and tilapia which strongly supported the present study. It was observed that Branchiomyces sp. recovered from affected gill of the infected fish species which caused the gill rot disease. Roberts et al. (1993) stated that gill rot disease is primary problem in many freshwater carp fishes and it was found when fish suffering from an environmental stress. It was observed that the value of physico-chemical parameters of sampling ponds decreased gradually from the months of November to January (comparatively cooler period). Highest incidences of infected fishes were recorded in those months. Mainly it was the peak time of outbreak of fungal disease. Chinabut (1994) worked on EUS and she found that this disease outbreak every year during November to February in Thailand. Barua (1994) reported that Saprolegnia sp. can grow at temperature ranging from $32^{\circ} \mathrm{F}$ to $95^{\circ} \mathrm{F}$ where poor water quality such as low circulation, low DO, or high ammonia are associated with Saprolegnia sp. infections. The authors also observed that 
environmental stress with low pH (5.8 to 6.5) and temperature $\left(57^{\circ} \mathrm{F}\right.$ to $95^{\circ} \mathrm{F}$ ) was most suitable for Banchiomyces sp. growth. Peckering and Willoughby (1982) stated that Saprolegnia sp. has a fairly wide range of temperature tolerance from $3{ }^{\circ} \mathrm{C}$ to $33{ }^{\circ} \mathrm{C}$, which appears to reflect the thermal preferences of the host.

\section{Conclusion}

It was observed that fungal disease varied in different months. The infestation rate was found to be high during the winter season. From the survey and histopathological findings, Cirrhinus mrigala was the most severely affected species, followed by Channa punctatus and Channa striatus which was the least affected species Heteropneustes fosillis. In present investigation fungal diseases appeared as a serious threat to the freshwater fishes in the study area which affected their biodiversity through being endangered and extinct.

\section{References}

Alam, M.Z., Ahmed, G.U., Alam, M.S. and Alam, M.T. 2003. Studies on fish diseases and limnological factors in Roktadaha Beel, Bogra. J. Bio-Sci. 11: 93-98.

Anonymous, 1992. Enigma of EUS. Consultation of EUS vis-a-vis the environment and the people, 25-26 May 1992. Summary of proceedings, International Collective in Support of Fish Workers, 27 C College Road, Madras 600006, India.

Barua, G. 1994. The status of epizootic ulcerative syndrome of fish of Bangladesh. Proceedings of the ODA Regional Seminar on Epizootic Ulcerative Syndrome. Aquatic Animal Health Research Institute, Bangkok, Thailand, 25-27 January 1994 (eds. R.J. Roberts, B. Chambell and I.H. MacRae). 13-20 pp.

Bruno, D. W. and Wood, B. P. 1994. Saprolegnia and other Oomycetes. In Fish Diseases and Disorder, Volume 3, Viral, Bacterial and Fungal Infections. Edited by P.T.K. Wood and D.W. Bruno. CABI publishing, Wallingford, Oxon, United Kingdom. 599-659 pp.

Chinabut, S. 1994. Environmental factors in relation to the epizotiology of EUS in Thailand. Proceedings of the ODA Regional Seminar on Epizootic Ulcerative Syndrome. Aquatic Animal Health Research Institute, Bangkok, Thailand, 25-27 January 1994 (eds. R.J. Roberts, B. Chambell and I.H. MacRae). 143-146 pp.

Chowdhury, M. B. R. 1993. Research priorities for microbial fish disease and its control in Bangladesh for fish health. In: Disease Prevention and Pathology, (ed. A. Tollervey), 8-11 pp.

Chowdhury, M. B. R. 1997. Involvement of aeromonads and pseudomonads diseases of farmed fish in Bangladesh. Proceedings of the International Symposium on Diseases in Marine Aquaculture, Hiroshima, 3-6 October 1997. Gyobyo-Knkyu, Fish pathology, 33: 4, 247-254.

Jewel, M. A. S. and Affan, M. A. 2003. Epizotic Ulcerative Syndrome (EUS) in fishes of small-scale farmers' ponds in Bogra district of Bangladesh. Univ. J. Zool. Rajshahi Univ., 22: 11-18.

McKenzie, R. A. and Hall, W. T. K. 1976. Dermal ulceration of Mullet (Mugil cephalus). Australian Vete. 52: $230-231$.

Myazaki, T. and Egusa, S. 1973. Studies on mycotic granulomatosis in freshwater fishes-IV. Mycotic granulomatosis in wild fishes. Fish Pathol., 8: 44-47.

Pechering, A. D. and Willoughby, L. G. 1982. In Microbial Dissease of Fish. Edited by R. J. Roberts. Academic Press, London, England. 271-297 pp.

Rab, A., Afzal, M., Akhtar, N., Barlas, A. and Qayyum, M. 2001. Incidence of Epizootic Ulcerative Systrome (EUS) in freshwater fishes in the endemic area of Punjab, Pakistan, Bangladesh J. Fish. Res., 5 (1): 45-52.

Roberts, R. J., Willoughby, L. G. and Chinabut, S. 1993. Mycotic aspects of Epizootic Ulcerative Syndrome (EUS) of Asian fishes. J. Fish.Dis., 16 (3): 169-183.

Snieszko, S. F. 1974. The effects of environmental stress on outbreaks of infectious disease of fishes. J. Fish Biol. 6: 197-208.

Willoughby, L. G. and Roberts, R. J. 1994. Improved methodology for isolation of the Aphanomyces fungal pathogen of Epizotice Ulcerative Syndrome (EUS), in Asian fishes. Proceedings of the ODA Regional Seminar on Epizootic Ulcerative Syndrome. Aquatic Animal Health Research Institute, Bangkok, Thailand, 25-27 January 1994 (eds. R.J. Roberts, B. Chambell and I.H. MacRae). 231-237 pp. 